\title{
ANALISIS HUBUNGAN PERILAKU MEROKOK DENGAN OBESITAS SENTRAL PADA ORANG DEWASA SEHAT DI SURADADI KABUPATEN TEGAL
}

\author{
Agus Susanto ${ }^{1}$, Eva Novita Sari ${ }^{2}$, Ratih Sakti Prastiwi ${ }^{3}$ \\ Politeknik Harapan Bersama \\ agussus@yahoo.com¹ evanovita386@gmail.com²r.sakti@poltektegal.ac.id ${ }^{3}$
}

\begin{abstract}
Central obesity is influenced by many factors such as changes in age, gender, economic status, life habits including lack of physical activity, low fiber consumption, consumption of simple carbohydrates, consumption of fatty foods and smoking behavior. Smoking behavior is thought to be a significant factor in forming central obesity in adult males. The purpose of this study was to determine the relationship between smoking behavior and central obesity in healthy adults. This study used an analytic observational design with a cross sectional research design. The research was conducted in Suradadi Village, Suradadi District, Tegal Regency. Sampling was carried out by stratified sampling in November 2020 - January 2021. The sample size was 90 men aged 25-60 years. Data were collected by measuring the waist circumference of the respondents and recording other personal data such as age, occupation and smoking status. Data processing is done descriptively and cross tabulation. Testing the relationship between smoking behavior and obesity was carried out using the chi-square statistical test with the help of the SPSS version 22 application. The majority of respondents in this study had a smoking status of $68.9 \%$ and did not have central obesity $64.4 \%$. The results of the test of the relationship between smoking status and central obesity got a p-value of 0.813. There is no significant relationship between smoking status and central obesity.
\end{abstract}

Keywords $\quad$ : Central Obesity, Healthy Adult, Smoking Behavior

\begin{abstract}
ABSTRAK
Obesitas Sentral Merupakan Kondisi Kelebihan Lemak Pada Perut (Abdomen). Obesitas Sentral Dipengaruhi Oleh Banyak Faktor Seperti Adanya Perubahan Umur, Jenis Kelamin, Status Ekonomi, Kebiasaan Hidup Meliputi Kurangnya Akitvitas Fisik, Rendahnya Konsumsi Serat, Konsumsi Karbohidrat Sederhana, Konsumsi Makanan Berlemak Dan Perilaku Merokok. Perilaku Merokok Disinyalir Sebagai Faktor Yang Signifikan Pembentuk Obesitas Sentral Pada Laki-Laki Dewasa. Tujuan Penelitian Ini Untuk Mengetahui Adanya Hubungan Perilaku Merokok Dengan Obesitas Sentral Pada Orang Dewasa Sehat. Desain Penelitian Ini Adalah Observasional Analitik Dengan Rancangan Penelitian Cross Sectional. Penelitian Dilaksanakan Di Desa Suradadi, Kabupaten Tegal. Pengambilan Sampel Dilakukan Secara Stratified Sampling Pada Bulan November 2020 - Januari 2021. Ukuran Sampel Ini Sebesar 90 Orang Laki-Laki Yang Berusia 25-60 Tahun. Data Diambil Dengan Cara Mengukur Lingkar Pinggang Responden Dan Mencatat Data Diri Lainnya Seperti Usia, Pekerjaan Dan Perilaku Merokok. Pengolahan Data Dilakukan Secara Deskriptif Dan Tabulasi Silang. Pengujian Hubungan Variabel Perilaku Merokok Dengan Obesitas Dilakukan Dengan Menggunakan Uji Statistik Chi-Square Dengan Bantuan Aplikasi SPSS Versi 22. Mayoritas Responden Memiliki Perilaku Merokok 68,9\% Dan Tidak Mengalami Obesitas Sentral 64,4\%. Hasil Uji Hubungan Antara Perilaku Merokok Dengan Obesitas Sentral Mendapatkan Nilai P (P-Value) Sebesar 0,813. Tidak Ada Hubungan Yang Bermakna Antara Perilaku Merokok Dengan Obesitas Sentral.
\end{abstract}

Kata Kunci : Obesitas Sentral, Orang Dewasa Sehat, Perilaku Merokok 


\section{PENDAHULUAN}

Obesitas sentral merupakan salah satu kondisi kesehatan yang terjadi karena adanya penimbunan lemak di perut. Obesitas sentral ditandai dengan lingkar pinggang lebih dari $90 \mathrm{~cm}$ untuk laki-laki dan lebih dari $80 \mathrm{~cm}$ untuk perempuan (Frisca, Karjadidjaja, \& Santoso, 2020). Penderita obesitas sentral semakin meningkat jumlahnya dari waktu ke waktu, khususnya di negara berkembang (Owolabi, Goon, \& Adeniyi, 2017).

Indonesia sebagai negara berkembang memiliki kasus obesitas yang cukup tinggi yaitu sebanyak 26,6\% pada tahun 2015 (Kementerian Kesehatan Republik Indonesia, 2015). Jumlah kasus obesitas sentral pada penduduk usia 15 tahun ke atas berdasarkan Riskesdas tahun 2018 di Jawa Tengah juga tinggi yaitu sebesar 24,7\%. (Badan Penelitian dan Pengembangan Kesehatan, 2018).

Berbeda dengan prevalensi obesitas nasional dan Provinsi Jawa Tengah, prevalensi obesitas di Kabupaten Tegal menduduki peringkat ke-23 dari seluruh wilayah provinsi Jawa Tengah. Prevalensi obesitas di kabupaten ini sebesar 3,02\% (Dinas Kesehatan Provinsi Jawa Tengah, 2020).

Obesitas sentral yang tidak diatasi dapat menyebabkan berbagai gangguan kesehatan. Beberapa gangguan penyakit yang disebabkan oleh obesitas sentral adalah diabetes melitus tipe 2, displidemia, penyakit kardiovaskular, hipertensi, kanker, sleep apnea, dan sindrom metabolik (Choi, Choi, Son, Oh, \& Park, 2019; Harvard Medical School, 2017). Beberapa faktor terkait dengan kejadian obesitas sentral meliputi faktor lingkungan dan sosial, gangguan sistem syaraf dan endokrin, faktor gaya hidup, konsumsi makanan tinggi lemak, konsumsi makanan berlebihan, perilaku merokok, dan konsumsi alkohol (Sudikno, Riyadina, \& Rahajeng, 2018).

Perubahan gaya hidup terkait perubahan pola makan dari tradisional ke kebiasaan makanan modern menyebabkan terjadinya overweight dan obesitas sentral. Selain perubahan gaya hidup, faktor lingkungan juga dapat berpengaruh seperti kebiasaan merokok.

Hubungan antara derajat perokok dengan adanya nikotin yang terdapat dalam rokok dan pengkonsumsian rokok, rendahnya tingkat aktivitas fisik, rendahnya konsumsi buah dan sayuran, dan tingginya konsumsi alkohol. Merokok dalam jangka waktu panjang dapat meningkatkan akumulasi lemak, obesitas sentral, dan resistensi insulin (Ruppercht, Donny, \& Sved, 2015; Septiyanti \& Seniwati, 2020).

Prevalensi perokok pada usia dewasa di Indonesia mengalami kenaikan sebesar $1 \%$, pada tahun 2016 dengan prevalensi perokok sebesar $32,8 \%$ menjadi $33,8 \%$ pada tahun 2018, sedangkan prevalensi perokok pada usia 15-24 tahun di kota Tegal sebesar $21,01 \%$, usia $25-34$ tahun sebesar 33,13\%, usia 45-54 tahun sebesar 30,07\% (Badan Penelitian dan Pengembangan Kesehatan, 2018; Kementerian Kesehatan RI, 2013).

Penelitian yang telah dilakukan oleh (Addo, Nyarko, Sackey, Akweongo, \& Sarfo, 2015; Lestari, 2017) menemukan bahwa pada responden yang merokok memiliki risiko 1,6 kali lebih besar mengalami overweight dibandingkan dengan yang tidak merokok. Selain itu, juga didapatkan hasil bahwa responden yang merokok memiliki risiko 1,3 kali lebih besar mengalami obesitas sentral dibandingkan dengan responden yang tidak merokok. Meski demikian beberapa penelitian memberikan hasil yang berbeda. Penelitian Lestari (2017) menunjukkan bahwa perilaku merokok tidak berhubungan dengan obesitas. Berkenaan dengan adanya perbedaan hasil penelitian, penelitian ini dimaksudkan untuk menguji lebih lanjut tentang hubungan antara perilaku merokok dengan obesitas. Penelitian ini bertujuan untuk membuktikan hubungan antara perilaku merokok dengan obesitas sentral.

\section{METODE}

Penelitian ini merupakan penelitian observasional analitik dengan rancangan penelitian cross sectional. Penelitian 
dilaksanakan pada bulan November 2020Januari 2021. Populasi penelitian adalah kepala keluarga yang berada di Desa Suradadi, Kecamatan Suradadi, Kabupaten Tegal. Populasi penelitian sebanyak 347 kepala keluarga. Berdasarkan populasi tersebut ukuran sampel penelitian ini adalah 90 kepala keluarga. Penarikan sampel berdasarkan kriteria insklusi berikut: kepala keluarga yang berusia 25-60 tahun dan bersedia menjadi responden. Peneliti meminta persetujuan responden dengan memberikan informed consent dan memberikan kebebasan kepada responden apabila ingin keluar dari kegiatan penelitian sebelum penelitian berakhir.

Instrumen penelitian ini adalah lembar observasi dan pita ukur. Prosedur pengumpulan data tentang obesitas sentral melalui pengukuran lingkar perut dengan pita ukur, sedangkan pengumpulan data karakteristik responden dengan mengajukan pertanyaan usia, pekerjaan dan perilaku merokok responden.

Analisis data dilakukan secara univariat dan bivariat. Analisis univariat dilakukan untuk mendeskripsikan tentang perilaku merokok dan status obesitas sentral. Analisis data dengan analisis bivariat dilakukan untuk mengetahui hubungan perilaku merokok dengan obesitas sentral.

\section{HASIL}

Hasil penelitian ini disajikan dalam secara deskriptif dan tabulasi silang. Penyajian secara deskriptif digunakan untuk menjelaskan karakteristik dan data dalam satu variabel dengan menyajikan frekuensi dan persentase. Tabulasi silang digunakan untuk menjelaskan hubungan antara perilaku merokok dengan obesitas sentral. Penyajian hasil penelitian ini secara berturut-turut adalah karakteristik responden, perilaku merokok, status obesitas dan uji hubungan antara perilaku merokok dan obesitas sentral. Penyajian hasil penelitian adalah sbenagai berikut:

Karakteristik responden yang pertama adalah berdasarkan usia responden.
Karakteristik berdasarkan usia tersaji dalam tabel 1 berikut:

Tabel 1. Usia Responden

\begin{tabular}{|c|c|c|c|}
\hline No. & Usia & $\mathbf{F}$ & $\%$ \\
\hline 1. & $\leq 35$ tahun & 23 & 25.6 \\
\hline 2. & $>35$ tahun & 67 & 74.4 \\
\hline & Total & 90 & 100.0 \\
\hline
\end{tabular}

Karaktersitik responden selanjutnya adalah berdasarkan jenis pekerjaan. Sebaran data tentang jenis pekerjaan responden tersaji dalam tabel 2 . berikut:

Tabel 2. Pekerjaan Responden

\begin{tabular}{llcc}
\hline No. & Pekerjaan & F & $(\boldsymbol{\%})$ \\
\hline 1. & PNS & 5 & 5.6 \\
2. & Wiraswasta & 25 & 27.8 \\
3. & Guru & 4 & 4.4 \\
4. & Pedagang & 21 & 23.3 \\
5. & Nelayan & 11 & 12.2 \\
6. & Petani & 6 & 6.7 \\
7. & Buruh & 11 & 12.2 \\
8. & Tidak bekerja & 7 & 7.8 \\
\hline & Total & 90 & 100.0 \\
\hline
\end{tabular}

Data dalam tabel 2 memperlihatkan bahwa jenis pekerjaan responden paling banyak adalah wiraswasta yaitu sebesar $27,8 \%$ dan diikuti dengan pedagang sebesar $23,3 \%$. Jenis pekerjaan yang paling sedikit adalah guru yaitu sebesar $4,4 \%$.

Hasil penelitian selanjutnya adalah perilaku merokok responden. Panelitian ini hanya membagi perilaku merokok responden dengan kategori merokok dan tidak merokok. Perilaku merokok responden tersaji dalam tabel 3 .

Tabel 3. Perilaku Merokok

\begin{tabular}{|c|c|c|c|}
\hline No. & $\begin{array}{l}\text { Perilaku } \\
\text { merokok }\end{array}$ & $\mathbf{F}$ & $(\%)$ \\
\hline 1. & Merokok & 62 & 68.9 \\
\hline \multirow[t]{2}{*}{2.} & Tidak Merokok & 28 & 31.1 \\
\hline & Total & 90 & 100.0 \\
\hline
\end{tabular}

Tabel 3 menunjukkan responden dengan perilaku merokok. lebih banyak yaitu $68,9 \%$ atau 62 responden, sedangkan sisanya ada 28 responden yang tidak merokok dengan presentase $31,1 \%$.

Hasil penelitian selanjutnya adalah status obesitas sentral yang dialami oleh 
responden. Hasil ini dapat dilihat dalam tabel 4. berikut:

Tabel 4. Status Obesitas Sentral

\begin{tabular}{llll}
\hline No. & Status Obesitas & $\mathbf{F}$ & $\mathbf{( \% )}$ \\
\hline 1. & Ya & 32 & 35.6 \\
2. & Tidak & 58 & 64.4 \\
\hline & Total & 90 & 100.0 \\
\hline
\end{tabular}

Tabel 4 menunjukkan frekuensi karakteristik responden berdasarkan status obesitas sentral. Berdasarkan data pada tabel 4 , menunjukkan bahwa 32 responden $(35,6 \%)$ mengalami obesitas sentral, sedangkan 58 responden $(64,4 \%)$ tidak mengalami obesitas sentral.

Hasil penelitian terakhir adalah tabulasi silang antara perilaku merokok dengan obesitas sentral. Hasil tabulasi silang tersaji dalam tabel 5. berikut:

Tabel 5. Hubungan antara Perilaku merokok dengan Obesitas Sentral

\begin{tabular}{llccccc}
\hline & & \multicolumn{4}{c}{ Status Obesitas } & \\
\cline { 3 - 5 } No & $\begin{array}{c}\text { Status } \\
\text { Merokok }\end{array}$ & Obesitas & \multicolumn{2}{c}{$\begin{array}{c}\text { Non } \\
\text { Obesitas }\end{array}$} & value \\
\cline { 3 - 5 } & & $\mathbf{F}$ & $\mathbf{\%}$ & $\mathbf{F}$ & $\mathbf{\%}$ & \\
\hline 1. & Merokok & 23 & 37.1 & 39 & 62.9 & \\
2. & Tidak & 9 & 32.1 & 19 & 67.9 & 0.813 \\
& merokok & & & & & \\
\hline & Total & 32 & 35.6 & 58 & 64.4 & \\
\hline
\end{tabular}

Tabel 5 menggambarkan bahwa terdapat 23 orang $(37,1 \%)$ merokok dan mengalami obesitas sentral dan 39 orang $(62,9 \%)$ merokok tetapi tidak mengalami obesitas sentral. Sejumlah 9 orang $(32,1 \%)$ tidak merokok tetapi mengalami obesitas sentral

\section{PEMBAHASAN}

Analisis data penelitian dari 90 responden memperlihatkan bahwa sebagian besar responden berusia > 35 tahun, yaitu sebanyak 67 orang $(74,4 \%)$. Responden berusia $\leq 35$ tahun lebih sedikit yaitu sebanyak 23 orang $(25,6 \%)$. Penelitian ini tidak berbeda jauh dengan penelitian yang dilakukan oleh Lestari (2017) yaitu didapatkan lebih banyak responden dengan usia 30-49 tahun sebagai prediksi obesitas.
Salah satu indikator pengukuran obesitas sentral yaitu pengukuran lingkar pinggang (Ticoalu, Wongkar, \& Pasiak, 2015). Obesitas sentral dapat diketahui melalui indikator rasio lingkar pinggang dan panggul (Djausal, 2015). Pengukuran obesitas pada penelitian ini dilakukan dengan mengukur lingkar pinggang responden. Menurut Ticoalu, Wongkar, \& Pasiak (2015) secara klinis penentuan obesitas sentral dapat dilakukan dengan menentukan lingkar pinggang karena kelebihan lemak abdominal terkait erat dengan faktor risiko penyakit degeneratif. Nilai cut of point lingkar pinggang yang digunakan dalam penelitian yaitu pria $\geq 90$ $\mathrm{cm}$ dan wanita $\geq 80 \mathrm{~cm}$ (International Diabetes Federation, 2006).

Data dalam tabel 4, menggambarkan bahwa 32 responden $(35,6 \%)$ mengalami obesitas sentral. Hasil penelitian ini sejalan dengan penelitian yang dilakukan oleh Lita (2016) dengan melakukan pengukuran lingkar pinggang pada 100 responden. Hasil penelitian tersebut menyatakan bahwa $40 \%$ responden mengalami obesitas sentral, sedangkan $60 \%$ responden tidak mengalami obesitas sentral. Temuan ini menunjukkan bahwa mayoritas perokok tidak mengalami obesitas sentral.

Penelitian yang dilaksanakan Arab Saudi menyatakan bahwa obesitas sering terjadi di antara mantan perokok dan paling tidak umum di antara perokok aktif. Selain itu, perokok aktif lebih kecil kemungkinannya untuk mengalami obesitas dibandingkan dengan yang tidak pernah merokok dan mantan perokok. (Ginawi et al., 2016). Beberapa studi juga menyatakan bahwa berhenti merokok menjadi faktor penting dalam peningkatan berat badan terutama pada jenis kelamin perempuan (Tuovinen et al., 2016; Watanabe et al., 2016). Bahkan dalam temuan Watanabe memperlihatkan perilaku merokok memiliki dampak anti-obesitas. Hal ini sebagai dampak nikotin dalam rokok yang berpontensi menekan nafsu makan perokok tersebut. Mantan perokok seringkali mengalami gangguan pola makan. 
Hasil uji Chi-Square menunjukkan bahwa $p$-value $>0,05$, yang berarti tidak ada hubungan yang bermakna antara perilaku merokok dengan obesitas sentral ( $p$-value 0,813 ). Penelitian tersebut menunjukkan tidak adanya hubungan bermakan antara perilaku merokok dengan obesitas sentral. Hasil penelitian ini sejalan dengan temuan Lestari, (2017). Penelitian ini menjelaskan bahwa perilaku merokok tidak memiliki hubungan dengan asupan gizi perokok yang berpontensi menyebabkan obesitas. Peningkatan intensitas dan jumlah konsumsi rokok justru berdampak pada penurunan berat badan (Plurphanswat \& Rodu, 2014).

Penelitian ini, merupakan penelitian dengan desain cross-sectional, yang berarti analisis terbatas pada hubungan kasual temporal antara perilaku merokok dengan obesitas. Hasil uji Chi-Square yang tidak menunjukkan hubungan yang bermakna antara kedua variabel kemungkinan terjadi karena distribusi yang tidak seimbang pada sampel dalam desain cross-sectional. Selain itu ketidak adanya hubungan ini juga disebabkan oleh faktor-faktor lain penyebab obesitas sentral yang lebih dominan di luar perilaku merokok seperti pola makan, intensitas aktivitas fisik, ataupun riwayat penyakit lainnya yang tidak digali oleh peneliti.

\section{KESIMPULAN}

Berdasarkan uji hubungan perilaku merokok dengan status obesitas sentral didapatkan hasil dari total 90 responden terdapat 62 responden yang berperilaku merokok dengan 23 responden $(37,1 \%)$ mengalami obesitas sentral dan 39 responden $(62,9 \%)$ tidak mengalami obesitas sentral. Sedangkan dari 28 responden yang tidak merokok terdapat 9 responden \%) 2,1\%) yang mengalami obesitas sentral. Berdasarkan hasil uji chi-square menunjukkan bahwa p-value > 0,05 yang berarti tidak terdapat hubungan yang signifikan antara perilaku merokok dengan status obesitas sentral dengan nilai $p$-value sebesar 0,813. Peneliti menyarankan kepada peneliti selanjutnya untuk melakukan penelitian dengan memperluas variabel supaya mendapatkan gambaran yang komprehensif tentang penyebab obesitas sentral.

\section{UCAPAN TERIMA KASIH}

Peneliti mengucapkan terima kasih kepada semua pihak yang telah membantu dan mendukung pelaksanaan penelitian ini, terkhusus kepada responden penelitian dan reviewer.

\section{DAFTAR PUSTAKA}

Addo, P., Nyarko, K., Sackey, S., Akweongo, P., \& Sarfo, B. (2015). Prevalence of obesity and overweight and associated factors among financial institution workers in Accra Metropolis, Ghana: a cross sectional study. BMC Research Notes, 8(1).

Badan Penelitian dan Pengembangan Kesehatan. (2018). Hasil Utama Riskesdas 2018. Jakarta.

Choi, D., Choi, S., Son, J. S., Oh, S. W., \& Park, S. M. (2019). Impact of Discrepancies in General and Abdominal Obesity on Major Adverse Cardiac Events. Journal of the American Heart Association, $8(18)$,

Dinas Kesehatan Provinsi Jawa Tengah. (2020). Profil Kesehatan Provinsi Jawa Tengah Tahun 2019. Semarang. Retrieved from www.dinkesjatengprov.go.id.

Djausal, A. N. (2015). Effect Of Central Obesity As Risk Factor Of Metabolic Syndrome. Jurnal Majority, 4(3).

Frisca, F., Karjadidjaja, I., \& Santoso, A. H. (2020). Prevalensi Obesitas Sentral Berdasarkan Lingkar Pinggang pada Pengemudi Bus Antar Kota. Jurnal Muara Sains, Teknologi, Kedokteran Dan Ilmu Kesehatan, 3(2), 231-236.

Ginawi, I. A., Bashir, A. I., Alreshidi, Y. Q., Dirweesh, A., Al-Hazimi, A. M., Ahmed, H. G., ... Ahmed, M. H. (2016). Association Between Obesity 
and Cigarette Smoking: A CommunityBased Study. Journal of Endocrinology and Metabolism, 6(5), 149-153.

Harvard Medical School. (2017). Abdominal obesity and your health - Harvard Health. Retrieved October 5, 2021, from

https://www.health.harvard.edu/stayinghealthy/abdominal-obesity-and-yourhealth

International Diabetes Federation. (2006). IDF Consensus Worldwide Definition of the Metabolic Syndrome. Retrieved October 5, 2021, from https://www.idf.org/e-

library/consensus-statements/60idfconsensus-worldwide-definitionofthe-metabolic-syndrome.html

Kementerian Kesehatan Republik Indonesia. (2015). 25 Januari, Hari Gizi Nasional. Retrieved October 5, 2021, from https://www.kemkes.go.id/article/view/ 15012300021/25-januari-hari-gizinasional.html

Kementerian Kesehatan RI. (2013). Pokok Pokok Hasil Riskesdas Provinsi Jawa Tengah 2013. Jakarta.

Lestari, D. I. (2017). Pengaruh Kebiasaan Merokok Terhadap Obesitas dan Overweight pada Karyawan Universitas DI Jakarta. Jurnal Muara Sains, Teknologi, Kedokteran Dan Ilmu Kesehatan, 1(1), 204-209.

Lita, M. M. (2016). Hubungan antara aktivitas fisik terhadap obesitas sentral pada orang dewasa sehat di Desa Kepuharjo Kecamatan Cangkringan Yogyakarta. Universitas Sanata Dharma, Yogyakarta.

Owolabi, E. O., Goon, D. Ter, \& Adeniyi, O. V. (2017). Central obesity and normalweight central obesity among adults attending healthcare facilities in Buffalo City Metropolitan Municipality, South Africa: a cross-sectional study. Journal of Health, Population, and Nutrition, 36(1).

Plurphanswat, N., \& Rodu, B. (2014). The association of smoking and demographic characteristics on body mass index and obesity among adults in the U.S., 1999-2012. BMC Obesity, 1(1).

Ruppercht, L. E., Donny, E. C., \& Sved, A. F. (2015). Obese Smokers as a Potential Subpopulation of Risk in Tobacco Reduction Policy. | Paper | Microsoft Academic. Yael Journal of Biologi and Medicine, 88(3), 289294.

Septiyanti, S., \& Seniwati, S. (2020). Obesity and Central Obesity in Indonesian Urban Communities. Jurnal Ilmiah Kesehatan, 2(3), 118127. https://doi.org/10.36590/JIKA.V2I3.7 4

Sudikno, S., Riyadina, W., \& Rahajeng, E. (2018). Obesitas Sentral Pada Orang Dewasa: Studi Kohor Prospektif di Kota Bogor. Gizi Indonesia, 41(2), 105-116.

Ticoalu, M. A. C., Wongkar, D., \& Pasiak, T. F. (2015). Angka Kejadian Obesitas Sentral pada Wanita di Desa Tumaluntung. E-Biomedik, 3(1).

Tuovinen, E. L., Saarni, S. E., Männistö, S., Borodulin, K., Patja, K., Kinnunen, T. H., ... Korhonen, T. (2016). Smoking status and abdominal obesity among normal- and overweight/obese adults: Population-based FINRISK study. Preventive Medicine Reports, 4, 324330.

Watanabe, T., Tsujino, I., Konno, S., Ito, Y. M., Takashina, C., Sato, T., ... Nishimura, M. (2016). Association between Smoking Status and Obesity in a Nationwide Survey of Japanese Adults. PLOS ONE, 11(3), e0148926. 